caemia" is consistently produced after a 12-hour fast irrespective of the time of day.

We wish to thank Dr. G. K. MoGowan for his advice and helpful comments.

\section{References}

Bowen, A. J., and Reeves, R. L. (1967). Archives of Internal Medicine, 119, 261.
Freinkel, N., Mager, M., and Vinnick, L. (1968). Fournal of Laboratory and Clinical Medicine, $71,171$.

Hansen, A. P., and Johansen, K. (1970). Diabetologia, 6, 27.

Hayner, N. S., Kjelsberg, M. D., Epstein, F. H., and Francis, T. (1965). Diabetes, 14, 413.

Jarrett, R. J., and Keen, H. (1969). British Medical fournal, 2, 341.

Jarrett, R. J., and Keen, H. (1969). British Medical fournal, 2, 341 .

Jarrett, R. J., Baker, I. A., Keen, H., and Oakley, N. W. (1972). British Medical fournal, 1, 199.

Moore, G. R., Barnes, I. C., and Pennock, C. A. (1972). Clinica Chimica Acta, 41, 439.

Rigas, A. N., Bittles, A. H., Hadden, D. R., and Montgomery, D. A. D. (1968). British Medical fournal, 4, 25.

\title{
Simultaneous Occurrence of Acute Myeloblastic Leukaemia and Multiple Myeloma without Previous Chemotherapy
}

\author{
THOMAS TURSZ, GEORGES FLANDRIN, JEAN-CLAUDE BROUET, JEAN BRIERE, \\ MAXIME SELIGMANN
}

British Medical Fournal, 1974, 2, 642-643

\section{Summary}

The simultaneous detection of multiple myeloma and acute myeloblastic leukaemia is reported in two patients who had not undergone chemotherapy. Histological examinations confirmed the infiltration by both myeloblasts and plasma cells. Only the latter contained monoclonal immunoglobulin chains at immunofluorescent studies. The possible relation between the two distinct proliferative processes is briefly discussed.

\section{Introduction}

The occurrence of acute myelomonocytic leukaemia or of acute myeloblastic leukaemia (A.M.L.) supervening on multiple myeloma (M.M.) (Kyle et al., 1970; Lancet, 1971) has now been recognized in about 30 patients who had undergone long-term chemotherapy with alkylating agents. The simultaneous detection of both M.M. and A.M.L. in previously untreated patients has not yet been described. It is thus of interest to report two such cases.

\section{Case 1}

A 77-year-old man was referred for a pancytopenia which had been discovered three years earlier. Physical examination showed nothing abnormal. Haemoglobin was $10 \mathrm{~g} / 100 \mathrm{ml}$; W.B.C. was $2,000 / \mathrm{mm}^{3}$ of which $44 \%$ were neutrophils and $55 \%$ were lymphocytes; the platelet count was $80,000 / \mathrm{mm}^{3}$ Bone marrow smears were hypercellular with $51 \%$ of peroxidase-positive myeloblastic cells and $23 \%$ of grossly dystrophic plasma cells. This picture was consistent with both M.M. and A.M.L.

The serum electrophoretic pattern showed a narrow spike $(1 \mathrm{~g} / 100$ $\mathrm{ml}$ ) which was identified as a monoclonal IgA $1 x$ on immunoelectrophoresis. The levels of IgG and IgM were greatly decreased. There was no proteinuria. The skeletal survey was normal.

\footnotetext{
Institut de Recherches sur les Maladies du Sang, H6pital SaintLouis, 75475 Paris

THOMAS TURSZ, M.D., Interne des Hôpitaux

GEORGES FLANDRIN, M.D., Chef de Travaux Assistant JEAN-CLAUDE BROUET, M.D., Chef de Clinique Assistant JEAN BRIERE, M.D., Chef de Clinique Assistant MAXIME SELIGMANN, M.D., Professeur d'Immunologie
}

The immunofluorescence study of the marrow cells with antisera to the various immunoglobulin chains showed that all the plasma cells contained alpha and kappa chains whereas the myeloblastic cells were negative for intracytoplasmic and membrane-bound immunoglobulins.

Postmortem examination showed a striking infiltration of the bone marrow and of the spleen by myeloblasts and plasma cells.

\section{Case 2}

A 74-year-old man had had a mild pancytopenia since 1967. Extensive haematological studies were performed in 1971. At that time physical examination showed nothing abnormal except a generalized purpura. Haemoglobin was $11 \mathrm{~g} / 100 \mathrm{ml}$; W.B.C. was $1800 / \mathrm{mm}^{3}$ of which $48 \%$ were neutrophils and $32 \%$ were lymphocytes; the platelet count was $60,000 / \mathrm{mm}^{3}$ Bone marrow smears were hypercellular with $51 \%$ of peroxidase-positive myeloblasts and $15 \%$ of plasma cells. A marrow biopsy showed an extensive invasion by both myeloblastic and plasma cells.

Serum electrophoresis disclosed a narrow spike $(2.5 \mathrm{~g} / 100 \mathrm{ml})$ which was identified on immunoelectrophoresis as a monoclonal IgG $\lambda$. The levels of polyclonal IgG, IgM, and IgA were very low. There was no proteinuria. Skeletal $x$-ray examination showed a mild osteoporosis. All plasma cells were shown to be strongly positive with antisera to gamma and lambda chains by intracytoplasmic immunofluorescence study whereas the myeloblastic cells were negative. Despite therapy with mercaptopurine the patient died a few months later. Necropsy was not performed.

\section{Discussion}

All previously reported patients in whom A.M.L. supervened on M.M. had been treated for 14 months to eight years with alkylating agents, mostly with melphalan. Many of these patients had also received local radiotherapy. A single patient reported by Videbaek (1971) had not been treated, but the diagnosis of A.M.L. seems very doubtful since the "blastic" cells were shown by immunofluorescence to contain immunoglobulin chains and were thus probably immature cells of plasmacytic origin, similar to those found in the patient reported by Thijs et al. (1970).

The leukaemogenic role of long-term chemotherapy is ruled out in our two patients. Other hypotheses should therefore be raised to explain the occurrence of both A.M.L. and M.M., and possibly the prolonged survival induced by therapy in M.M. patients may offer the opportunity to observe hitherto unrecognized aspects of the natural history of M.M. The humoral immune defect in myeloma may facilitate the emergence of other neoplastic clones. A common aetiological agent could be 
responsible for the development of both proliferations since the occurrence of myelomonocytic leukaemia has been noted by Warner et al. (1969) in BALB/c mice after intraperitoneal injection of mineral oil, a stimulus usually leading to plasmacell tumours. Osserman (1967) stressed the possibility that the chronic stimulation of the reticuloendothelial system may lead to the development of both monocytic and plasmacytic dyscrasias. Though many cases of acute leukaemia supervening on M.M. were labelled as "myelomonocytic" leukaemia, it is worth noting that though lysozyme levels were not studied our two patients apparently had true A.M.L.

Khaleeli et al. (1973) recently described four patients with M.M. who developed sideroblastic anaemia several months before the occurrence of acute leukaemia. It is interesting, therefore, to note that a pancytopenia was found in both our patients three to four years before diagnosis. In two other patients with M.M. we found an unusual myeloid hyperplasia with splenomegaly and 30,000-50,000 white blood cells with $90-95 \%$ of mature neutrophils. In one of these patients acute leukaemia developed four years later after treatment with melphalan.
The relation between M.M. and A.M.L., which involve distinct cell lines, remains puzzling. Long-term chemotherapy may have only a triggering role in patients with M.M. and some kind of pre-leukaemia state.

We thank Dr. Jean-Louis Preud'Homme for performing the immunofluorescence examinations. These studies were supported by I.N.S.E.R.M. (U 108).

\section{References}

Khaleeli, M., Keane, W. M., and Lee, G. R. (1973). Blood, 41, 17.

Kyle, R. A., Pierre, R. V., and Bayrd, E. D. (1970). New England fournal of Medicine, 283, 1121.

Lancet. (1970). 1, 70 .

Osserman, E. F. (1967). In Gamma Globulins: Structure and Control of Biosynthesis, ed. J. Killander, p. 573. Stockholm, Almqvist and Wiksell. Thijs, L. G., et al. (1970). British fournal of Haematology, 19, 485. Videbaek, A. (1971). British Medical fournal, 2, 326.

Warner, N. L., Moore, M. A. S., and Metcalf, D. (1969). Fournal of the National Cancer Institute, 43, 963.

\section{PRELIMINARY COMMUNICATION}

\section{T-lymphoblastic Leukaemia: A Distinct Variant of Acute Leukaemia}

\author{
D. CATOVSKY, J. M. GOLDMAN, A. OKOS, \\ B. FRISCH, D. A. G. GALTON
}

British Medical fournal, 1974, 2, 643-646

\section{Summary}

Two cases of acute lymphoblastic leukaemia (A.L.L.) of T-cell type are reported. Clinically they were characterized by very high peripheral blood blast cell counts at presentation, the early development of meningeal leukaemia, and relative resistance to treatment with combination chemotherapy. Leukaemic cells from both patients lacked all the B-cell markers investigated, but $60-65 \%$ of their cells formed rosettes with sheep red cells. Cytochemical and surface structure studies helped to define additional features of these cells and confirmed their $T$-cell nature.

It seems that this variant of A.L.L. may not be uncommon and that it can be distinguished on clinical and immunological grounds from the usual type of A.L.L. which runs a less aggressive course and lacks $B$ - or $T$-cell markers.

\section{Introduction}

The improvement in rate of remission and survival in acute ("childhood") lymphoblastic leukaemia (A.L.L.) (Spiers, 1972 a)

\footnotetext{
M.C. Leukaemia Unit and Department of Haematology, Royal Postgraduate Medical School, London W12 0HS

D. CATOVSKY, M.D., Lecturer in Haematology

J. M. GOLDMAN, B.M., M.R.C.P., Honorary Consultant Physician

A. OKOS, M.D., Research Fellow

B. FRISCH M.D., Research Fellow

D. A. G. GALTÖN, M.D., F.R.C.P., Director of M.R.C. Unit
}

is the major factor that has led to a more optimistic approach to A.L.L., which is still considered to be a homogeneous disease. Certain "bad-risk" cases are now recognized, however. For example, patients who have high blast cell counts, organomegaly, or marked thrombocytopenia at presentation fare relatively badly and also have a higher risk of developing meningeal leukaemia (Pavlovsky et al., 1973). It has been suggested that patients with large blast cells (macroblasts) may obtain little benefit from immunotherapy (Mathé et al., 1971), but morphological features are highly subjective and agreement between different centres is poor. A classification based on more objective criteria would be extremely valuable if specific cellular features could be shown to correlate with prognosis. In recent years markers for lymphoid cell differentiation have been used in the study of lymphoproliferative disorders. Though most cells from patients with A.L.L. seem to lack the surface markers for B and T lymphocytes (Lay et al., 1971; Smith et al., 1973 a) evidence is now accumulating that a significant minority may in fact be of T-cell type (Seligmann et al., 1973; Borella and Senn, 1973; Kersey et al., 1973; McCaffrey et al., 1973). Furthermore, it has been suggested that the T-cell form of the disease is more aggressive (Borella and Sen, 1973). We studied two further cases of $\mathrm{T}$-lymphoblastic leukaemia in which its aggressive clinical course, in contrast to the usual type of A.L.L., was clearly shown.

We report here the results of these studies because we believe that the immunological tests described should be applied to all new cases of A.L.L. The recognition of the T-lymphocyte origin of a proportion of cases of A.L.L. seems to have important therapeutic implications, but its true incidence cannot be assessed until a much larger series of patients has been studied.

\section{Case 1}

A 14-year-old boy was admitted to Hammersmith Hospital in December 1973 with a two-week history of spontaneous bruising. He had a petechial rash distributed symmetrically over the anterior aspect of the trunk. The spleen was palpable $6 \mathrm{~cm}$ below the costal margin, but the liver was not enlarged. There was no clinical or radiological evidence of mediastinal enlargement. The peripheral blood showed a haemoglobin of $10.1 \mathrm{~g} / 100 \mathrm{ml}$, total leucocytes 1,004,000/ml and platelets $52,000 / \mu \mathrm{l}$. The differential count showed $95 \%$ blast cells with nuclear chromatin aggregation suggestive of lymphocytic differentiation (fig. 1). The bone marrow 